\title{
A comparative study of nutritional composition and potential use of some underutilized tropical fruits of Arecaceae
}

\author{
RAQUEL B. SILVA ${ }^{1}$, EDVALDO V. SILVA-JÚNIOR ${ }^{1}$, LAÍS C. RODRIGUES ${ }^{1}$, LAISE H.C. ANDRADE ${ }^{1}$, \\ SUZENE I. DA SILVA ${ }^{2}$, WOLFGANG HARAND ${ }^{3}$ and ANTONIO F.M. OLIVEIRA ${ }^{1}$ \\ ${ }^{1}$ Departamento de Botânica, Laboratório de Ecologia Aplicada e Fitoquímica, Universidade Federal \\ de Pernambuco, Rua Prof. Moraes Rego, s/n, Cidade Universitária, 50670-901 Recife, PE, Brasil \\ ${ }^{2}$ Departamento de Biologia, Laboratório de Recursos Econômicos e Fitoquímica, Universidade Federal \\ Rural de Pernambuco, Rua Dom Manoel de Medeiros, s/n, Dois Irmãos, 52171-900 Recife, PE, Brasil \\ ${ }^{3}$ Centro de Tecnologias Estratégicas do Nordeste, Avenida Professor Luiz Freire, 01, \\ Cidade Universitária, 50740-540 Recife, PE, Brasil
}

Manuscript received on April 14, 2014; accepted for publication on December 15, 2014

\begin{abstract}
In this study, pulp and kernel of fruits from six Arecaceae species were subjected to proximate analysis, fatty acid composition and total carotenoid content analysis. The species with the highest carbohydrate, lipid and protein values were Ptychosperma macarthurii (70.1 g/100 g in the kernel), Syagrus cearensis ( $40.6 \mathrm{~g} / 100 \mathrm{~g}$ in the kernel), and $S$. coronata $(20.6 \mathrm{~g} / 100 \mathrm{~g}$ in the pulp). The ash content ranged from 0.61 to $7.51 \mathrm{~g} / 100 \mathrm{~g}$. Lauric, palmitic, and oleic acids were the major fatty acids identified. The total carotenoid contents and retinol activity equivalents were highest in the Pinanga kuhlii $(180.3 \mu \mathrm{g} / \mathrm{g})$ and Acrocomia intumescens $(138.0 \mu \mathrm{g} / \mathrm{g})$ pulp oils. Retinol activity equivalents varied between the investigated species (456 to 1515 $\mu \mathrm{g}$ RAE/100 g). Native species such as A. intumescens, S. coronata, and S. cearensis are good sources of fresh food for the underserved populations that inhabit poorly developed areas such as the semi-arid region of Brazil. P. macarthurii, an exotic species, is an excellent source of ash and carotenoids, demonstrating its potential both as a food source and as bioactive compounds. Pulp and kernel of $A$. intumescens, could be a good alternative feedstock for soap and biodiesel production, respectively.
\end{abstract}

Key words: biomass, foods, oleic acid, palm trees.

\section{INTRODUCTION}

Numerous species from different Brazilian ecosystems are appreciable sources of amino acids, carbohydrates, fatty acids, fiber, protein, and minerals (Mayworm et al. 1996, Pinho et al. 2009, Oliveira et al. 2012). Other natural compounds, such as carotenoids, also have a wide range of benefits to human health, mainly due

Correspondence to: Antonio Fernando M. Oliveira

E-mail: afmoliveira@pq.cnpq.br to their antioxidant properties, which protect the human body against oxidative stress and serve as precursors of vitamin A. Thus, the intake of carotenoid-rich vegetables is very important (Rodriguez-Amaya and Kimura 2004).

Despite the species diversity in Brazil, many of these species are still poorly exploited as industrial feedstock. Located in the Brazilian semi-arid region, the Caatinga, is a seasonal dry tropical forest characterized by dry, spiny and 
predominantly deciduous shrub/forest vegetation. The Caatinga has crucial importance for people who inhabit this region, and it provides a wide variety of plants that are used as fuel, building materials and medicinal resources (Nascimento et al. 2011, 2012). However, few species are actually used by small local industries, despite the semi-arid region having approximately 6000 species of angiosperms.

Arecaceae is one of the largest botanical families of economic importance. It comprises 2600 species in 240 genera. In Brazil, the family is represented by 38 genera and 269 species (Leitman et al. 2014). The Arecaceae flora of the Brazilian Northeast includes 80 native species and in the Pernambuco state (northeast Brazil), there are 17 species registered (Leitman et al. 2014), most of which have some economic value (Medeiros-Costa 2002, Rufino et al. 2008).

Although some of the Arecaceae species, including some species from Brazil, have been previously analyzed for centesimal composition (Crepaldi et al. 2000, Hiane et al. 2003, Menezes et al. 2008, Teixeira da Silva de La Salles et al. 2010, Coimbra and Jorge 2011), there is still a lack of research on the industrial applications of some palm trees. The aim of this work was to perform proximate analysis, fatty acid composition determination and total carotenoid analysis of the fruits of six tropical Arecaceae, some of which have not been reported to date, to evaluate their potential use as food and for other industrial purposes.

\section{MATERIALS AND METHODS}

Plant Materials

The species were selected based mainly on the results of previous ethnobotanical studies, on their economic importance and on underexploited potential (Medeiros-Costa 2002, Lorenzi et al. 2004). Fruit samples from Acrocomia intumescens
Drude, Pinanga kuhlii Blume, Ptychosperma macarthurii (H. Wendl. ex H.J. Veitch) H. Wendl. ex Hook. f., Syagrus cearensis Noblick, Syagrus coronata Mart. (Becc.) and Veitchia merrillii (Becc.) H.E. Moore were collected between January and September of 2011 in Recife, Garanhuns and Buíque (Northeastern Brazil). The fruits were stored at $4{ }^{\circ} \mathrm{C}$ until the chemical analysis was performed.

MOISTURE AND ASH

The pulp and kernel (5 g each) were dried overnight at $105{ }^{\circ} \mathrm{C}$ in accordance to AOAC method 930.15 (AOAC 2000). The moisture percentage was calculated by subtracting the dry weight from the wet weight. After determining the moisture content the pulp and kernel were placed in a porcelain crucible and incinerated in a muffle furnace (Tecnal, 11001P, Piracicaba, Brazil) at $550^{\circ} \mathrm{C}$ until light gray ash resulted, in accordance with AOAC method 923.03 (AOAC 2000). The crucibles were transferred to a desiccator and cooled to room temperature. The loss in mass was determined gravimetrically.

TOTAL LIPIDS AND FATTY ACID METHYL EsTER ANALYSIS

The pulp and kernel ( $5 \mathrm{~g}$ each) were dried at $45^{\circ} \mathrm{C}$, powdered and extracted with $n$-hexane $\left(60-80^{\circ} \mathrm{C}\right)$ for $8 \mathrm{~h}$ in a Soxhlet extractor (Ahmad 1981). The oil content of the pulp and kernel was calculated by dividing the initial weight by the weight of the extracted lipids. The oil from each fruit pulp and kernel was hydrolysed (separately) at $100{ }^{\circ} \mathrm{C}$ for $10 \mathrm{~min}$ in a water bath with $1.5 \mathrm{~mL}$ of $\mathrm{KOH}$ in methanol $(0.5 \mathrm{M})$. After cooling on ice for $5 \mathrm{~min}, 2.5 \mathrm{~mL}$ of $14 \%$ boron trifluoride methanolic (Sigma-Aldrich, St. Louis, Missouri) was added, and the sample was placed in a water bath for $30 \mathrm{~min}$ and then cooled again for $5 \mathrm{~min}$. After methylation, $2.5 \mathrm{~mL} \mathrm{NaCl}(1 \%)$ and $3 \mathrm{~mL}$ of $n$-heptane were added, and the sample was centrifuged at $730.8 \mathrm{~g}$ for $5 \mathrm{~min}$. The organic phase was collected, and excess moisture was removed by adding $0.1 \mathrm{~g}$ of anhydrous $\mathrm{Na}_{2} \mathrm{SO}_{4}$. 
The free fatty acids methylated were analyzed by GC/FID and GC/MS (QP5050 Shimadzu, Kyoto, Japan). The oven temperature was started at $150{ }^{\circ} \mathrm{C}$, and then was increased to $250{ }^{\circ} \mathrm{C}$ at $4{ }^{\circ} \mathrm{C} /$ min and held for $20 \mathrm{~min}$. The chromatograph was equipped with a capillary DB-column and helium was used as the carrier gas with a flow rate of 1 $\mathrm{cm}^{3} / \mathrm{min}$. The detector and injector temperatures were set to $280{ }^{\circ} \mathrm{C}$. The injection volume was 1.0 $\mu \mathrm{L}$, and the split ratio was 30:1. All mass spectra were acquired using the electron impact (EI) mode at $70 \mathrm{eV}$. Fatty acids were identified as methyl esters by comparison using authentic standard (FAME Supelco $^{\mathrm{TM}}$ mix C4-C24, Bellefonte, PA, USA) and by comparison with mass spectra in the Wiley 229 database (Wiley, New York) and the NIST/EPA/NIH Mass Spectral Library (NIST05). The relative amount of the FAME was calculated from the integrated area of each peak and expressed as a percentage of the total area of all peaks.

\section{PROTEINS}

The pulp and kernel ( $5 \mathrm{~g}$ each) were dried at room temperature (approximately $30{ }^{\circ} \mathrm{C}$ ) under forced blowing until the sample reached a constant weight, after which the sample was ground to a powder form. The crude protein was determined by the Kjeldahl method in accordance with AOAC method 960.52 (AOAC 2000). The protein percentage was calculated using conversion factors of 6.25 and 5.30 for the pulp and the kernel, respectively (Jones 1941).

\section{CARBOHYDRATES AND ENERGY}

The carbohydrates content, including fiber, was calculated by subtraction of the sum of the crude protein, total fat, moisture, and ash. The energy content was calculated by multiplying the mean values of lipids, proteins, and total carbohydrate by their respective caloric values: $37 \mathrm{~kJ} / \mathrm{g}(9.0 \mathrm{kcal} / \mathrm{g})$, $17 \mathrm{~kJ} / \mathrm{g}(4.0 \mathrm{kcal} / \mathrm{g})$, and $17 \mathrm{~kJ} / \mathrm{g}(4.0 \mathrm{kcal} / \mathrm{g})$, respectively (Atwater factors). The results were expressed as $\mathrm{kJ} / 100 \mathrm{~g}$.

\section{TOTAL CAROTENOIDS DETERMINATION}

The oil from the pulp or the kernel ( $1 \mathrm{~g}$ each) was separated and diluted in $100 \mathrm{~mL}$ of petroleum ether $\left(60-80{ }^{\circ} \mathrm{C}\right)$, and the absorbance was measured at 450 $\mathrm{nm}$ in a Genesys 10S UV/VIS spectrophotometer (Thermo Scientific, Waltham, MA, USA), in accordance with Rodriguez-Amaya et al. (2008). The carotenoid content was expressed as $\beta$-carotene equivalents $(\mu \mathrm{g} / \mathrm{g})$. The retinol activity equivalent (RAE) levels were calculated using a conversion factor of $1 \mu \mathrm{g}$ retinol to $12 \mu \mathrm{g}$ of dietary all-trans$\beta$-carotene and were expressed in $\mu \mathrm{g}$ RAE/100 g (IOM 2001).

\section{Statistical AnALYSES}

At least three replications of the experiment were performed. The data were analyzed by One-way ANOVA and Tukey's HSD test. All tests were set at 0.05 level of significance and analyzed using GraphPad Prism software (GraphPad, San Diego, CA, USA).

\section{RESULTS}

The results of the proximate analysis for the six Arecaceous fruits studied are shown in Table I. All studied species, except $P$. kuhlii, had high levels of moisture (ranging from 60 to $75 \%$ ). In most species, the pulp had more moisture than the kernel. In $P$. macarthurii, the moisture values were the same for the pulp and the kernel. S. coronata, V. merrillii, and $S$. cearensis showed higher moisture content in the pulp when compared with the other species studied (74.94, 74.40 and $72.57 \mathrm{~g} / 100 \mathrm{~g}$, respectively).

In the palm trees studied, the ash contents ranged from 0.56 to $7.51 \mathrm{~g} / 100 \mathrm{~g}$ in the pulp and from 1.04 to $7.12 \mathrm{~g} / 100 \mathrm{~g}$ in the kernel. The greatest amount of ash (more than $7 \mathrm{~g} / 100 \mathrm{~g}$ ) was found in the pulp and kernel of $P$. macarthurii and $S$. cearensis, respectively (Table I). The ash content in the pulp of $P$. kuhlii was also very high $(6.36 \mathrm{~g} / 100 \mathrm{~g})$. The ash content of the pulps of $S$. 
TABLE I

Proximate analysis and calorific values of some tropical fruits of Arecaceae from northeastern Brazil.

\begin{tabular}{ccccccc}
\hline \multirow{2}{*}{ Species } & \multicolumn{7}{c}{ Proximate analysis (g/100 g) } & \\
\cline { 2 - 6 } & moisture & ash & proteins & carbohydrates & lipids & energy (kJ/100 g) \\
\hline Acrocomia intumescens & $62.2 / 14.8$ & $2.0 / 2.0$ & $2.5 / 11.7$ & $3.5 / 43.9$ & $29.6 / 27.4$ & $1200 / 1960$ \\
Pinanga kuhlii & $22.9 / 48.2$ & $6.3 / 1.4$ & $5.1 / 7.2$ & $64.0 / 40.6$ & $1.5 / 2.3$ & $1231 / 902$ \\
Ptychosperma macarthurii & $65.4 / 65.4$ & $7.5 / 1.6$ & $4.8 / 7.1$ & $14.2 / 70.1$ & $8.0 / 0.8$ & $621 / 134$ \\
Syagrus cearensis & $72.5 / 24.3$ & $0.6 / 7.1$ & $4.3 / 4.4$ & $19.2 / 23.3$ & $3.1 / 40.6$ & $518 / 1977$ \\
Syagrus coronata & $74.9 / 12.5$ & $0.5 / 3.2$ & $20.6 / 4.3$ & $16.0 / 33.4$ & $1.5 / 30.0$ & $680 / 1754$ \\
Veitchia merrillii & $74.4 / 44.3$ & $1.4 / 1.0$ & $1.5 / 2.6$ & $11.6 / 51.2$ & $10.9 / 0.6$ & $629 / 942$ \\
\hline
\end{tabular}

${ }^{a}$ Values represent the proximate analysis and calorific values from pulp and kernel, respectively, from five grams of dried fruits. The protein percentage was calculated using a conversion factor of 6.25 and 5.30 for pulp and kernel, respectively and the energy content was based on Atwater factors (see materials and methods section for detailed explanation). Standard error not shown in order to improve clarity of the table.

cearensis and S. coronata were similar, but the ash content of the kernel was two and a half times higher in $S$. cearensis than in $S$. coronata. Of all samples analyzed, the fruits of $V$. merrillii had the lowest ash content (lower than $2 \mathrm{~g} / 100 \mathrm{~g}$ ).

For most of the species, the macronutrient analyses indicated that the total protein concentration was relatively low (Table I), but it was always higher in the kernel than in the pulp. One exception was observed in $S$. coronata, the species with the greatest amount of protein in the pulp $(20.64 \mathrm{~g} / 100 \mathrm{~g})$. In contrast, the protein content in the pulp of $S$. cearensis was almost five times lower than that observed in $S$. coronata.

The proximate analysis for the carbohydrate content showed that the kernels instead of the pulps are the major sources of sugar (Table I). The six species studied had the highest carbohydrate content in the kernel (ranging from 23.36 to 70.12 $\mathrm{g} / 100 \mathrm{~g})$. The highest carbohydrate content was observed in the $P$. macarthurii and A. intumescens kernels (70.12 and $43.91 \mathrm{~g} / 100 \mathrm{~g}$, respectively). Unlike other species, $P$. kuhlii exhibited a significant carbohydrate content in the pulp $(64.03 \mathrm{~g} / 100 \mathrm{~g})$.

Among the six species analyzed, only three contained high lipid contents (Table I). The greatest oil content was found in the kernels of $S$. coronata and S. cearensis (40.64 and $30.04 \mathrm{~g} / 100 \mathrm{~g}$, respectively).
The fruits of $A$. intumescens had a similar oil content in their pulp (29.61 g/100 g) and kernel (27.42 g/100 g). The other studied species had a low quantity of oil, particularly P. kuhlii (less than $3 \mathrm{~g} / 100 \mathrm{~g}$ ). Based on crude protein, lipid and total carbohydrate contents, the calorific values of the fruits ranged from 518 to $1977 \mathrm{~kJ} / 100 \mathrm{~g}$ (Table I). Due to the higher carbohydrate content in the kernel and the lipid content in the pulp, the fruit of $A$. intumescens exhibited the highest overall energy value (1200 and $1960 \mathrm{~kJ} / 100 \mathrm{~g}$, respectively).

Lauric, palmitic and oleic acids were the main fatty acids identified (Table II). Lauric acid predominated in the kernels of $A$. intumescens (45.44\%) and in the two Syagrus species (38.11 to $44.55 \%$ ), while palmitic acid was predominant in the kernels of $P$. macarthurii (92.61\%). Oleic acid was markedly dominant in the pulps, particularly in A. intumescens (74.14\%). Linoleic acid was identified only in the pulp oils of $P$. macarthurii and A. intumescens.

As shown in Table III, the total carotenoid contents, expressed as $\beta$-carotene equivalents, were significantly higher in the pulp oils than in the kernels. The total carotenoid contents of the kernels were similar in most species. P. kuhlii and $A$. intumescens exhibited the highest carotenoid contents (180.3 and $138.0 \mu \mathrm{g} / \mathrm{g}$, respectively). 
TABLE II

The fatty acid compositions of some fruits of Arecaceae from northeastern Brazil.

\begin{tabular}{|c|c|c|c|c|c|c|c|}
\hline \multicolumn{8}{|c|}{ Fatty acids composition $(\%)^{a}$} \\
\hline & C10:0 & C12:0 & C14:0 & C16:0 & C18:0 & C18:1 & C18:2 \\
\hline Acrocomia intumescens & $-/ 5.03$ & $-/ 45.44$ & $-/ 12.61$ & $14.08 / 9.53$ & $-/ 4.31$ & $74.14 / 23.07$ & $11.78 /-$ \\
\hline Pinanga kuhlii & $-/-$ & $7.12 /-$ & $-/-$ & $31.28 / 45.20$ & $-/-$ & $11.81 /-$ & $-/-$ \\
\hline Ptychosperma macarthurii & $-/-$ & $-/-$ & $-/-$ & $41.89 / 92.91$ & $4.91 /-$ & $28.79 /-$ & $23.60 /-$ \\
\hline Syagrus cearensis & $-/ 3.44$ & $-/ 38.11$ & $-/ 3.37$ & $34.40 /-$ & $-/-$ & $28.33 /-$ & $-/-$ \\
\hline Syagrus coronata & $-/ 9.16$ & $-/ 44.55$ & $-/ 19.04$ & $42.31 / 10.03$ & $32.35 / 3.78$ & $25.34 / 13.44$ & $-/-$ \\
\hline Veitchia merrillii & $-/-$ & $-/ 4.76$ & $-/-$ & $36.58 / 36.89$ & $20.17 / 15.58$ & $-/-$ & $-/-$ \\
\hline
\end{tabular}

${ }^{\mathrm{a}}$ Values represent the fatty acids composition from pulp and kernel, respectively. C10:0 = capric acid, C12:0 = lauric acid, C14:0 $=$ myristic acid, $\mathrm{C} 16: 0=$ palmitic acid, 18:0 $=$ stearic acid, C18:1 $=$ oleic acid, and C18:2 = linoleic acid. $-=$ Not detected or trace amounts. Standard error not shown in order to improve clarity of the table.

TABLE III

The total carotenoid contents and retinol activity equivalents of some fruits of Arecaceae from northeastern Brazil.

\begin{tabular}{cccc}
\hline Species & \multicolumn{2}{c}{ Carotenoids content $(\boldsymbol{\mu g} / \mathbf{g})^{*}$} & $\begin{array}{c}\text { Total RAE } \\
(\boldsymbol{\mu g} / \mathbf{1 0 0} \mathbf{g})\end{array}$ \\
\cline { 2 - 3 } & $\mathbf{p u l p}$ & $\mathbf{k e r n e l}^{\mathrm{a}}$ & 1166 \\
Acrocomia intumescens & $138.0 \pm 5.2^{\mathrm{b}}$ & $1.9 \pm 0.7^{\mathrm{a}}$ & 1515 \\
Pinanga kuhlii & $180.3 \pm 2.7^{\mathrm{a}}$ & $1.5 \pm 0.5^{\mathrm{a}}$ & 652 \\
Ptychosperma macarthurii & $77.9 \pm 3.1^{\mathrm{c}}$ & $0.4 \pm 0.2^{\mathrm{b}}$ & 456 \\
Syagrus cearensis & $54.1 \pm 1.2^{\mathrm{d}}$ & $0.7 \pm 0.2^{\mathrm{b}}$ & 731 \\
Syagrus coronata & $87.0 \pm 1.3^{\mathrm{c}}$ & $0.7 \pm 0.3^{\mathrm{b}}$ & 592 \\
Veitchia merrillii & $70.7 \pm 2.8^{\mathrm{c}}$ & $0.4 \pm 0.2^{\mathrm{b}}$ & \\
\hline
\end{tabular}

*Values represent the total carotenoids based on $\beta$-carotene from $5 \mathrm{~g}$ of dried fruits and are mean \pm SD of three determinations. Values with same letters are not significantly different by the Tukey test $(P>0.05)$. Total RAE $=$ retinol activity equivalents from the pulp and kernel combined, where $1 \mu \mathrm{g}$ retinol is equal to $12 \mu \mathrm{g}$ of dietary all-trans- $\beta$-carotene matrix (see materials and methods section for detailed explanation).

The total carotenoid contents differed significantly between Syagrus species. Due to the large amount of carotenoids, $P$. kuhlii and A. intumescens showed higher retinol activity equivalent values (1515 and $1166 \mu \mathrm{g} / 100 \mathrm{~g}$ RAE, respectively).

\section{DISCUSSION}

In general, the proximate analysis data for six palms species studied were similar to values previously reported in other studies of Arecaceae species. Lipids were the main constituents of the dried kernels of the two Syagrus species studied. $S$. cearensis had the highest oil content and the second greatest caloric value. The fat content of $S$. cearensis was greater than that of $S$. coronata
(Table I), but it was almost two times lower than that reported by other authors for the same species (Nascimento et al. 2011). The oil content in the kernel of $S$. coronata was also one and a half times less than a previously reported value (Crepaldi et al. 2000). These discrepancies are likely due to the higher moisture content found in our analyses.

Despite the similar lipid content in $S$. coronata and $S$. cearensis (Table I), these species can be distinguished by the high protein content in the pulp of S. coronata $(20.64 \%)$. This high protein value is comparable to that of other species traditionally used as foods, such as black beans (Trugo et al. 2000). Since protein and lipid predominates, respectively, in the pulp and kernel of $S$. coronata, 
the consumption of whole fruit as a flour is more indicated to permit the use of both macronutrients.

P. kuhlii, P. macarthurii, and V. merrillii are three exotic species that are widely grown in Brazil as ornamental trees (Lorenzi et al. 2004). Although no other use has been suggested for these species, our study showed that the P. kuhlii pulp and the P. macarthurii kernel could provide alternative sources of carbohydrates (Table I). P. macarthurii, which occurs naturally in Australia (Jones 2010), but in Brazil is an exotic species used in urban and domestic landscapes, was also a good source of ash and palmitic acid (in the kernel and the pulp, respectively). Although the nutritional potential of these species is rarely reported, the high carbohydrate and ash contents of P. kuhlii and P. macarthurii are similar to those of other traditional tropical palm trees such as A. aculeata, Euterpe oleracea Mart., Phoenix dactylifera L., Syagrus oleracea (Mart.) Becc, and S. romanzoffiana (Cham.) Glassman (Bora et al. 2003, Menezes et al. 2008, Coimbra and Jorge 2011).

In our study, the Syagrus species and $A$. intumescens were the most energetic, due to their higher oil and carbohydrate concentrations. The caloric value of $S$. coronata, shown in Table I, is similar to a previously reported value (Crepaldi et al. 2000). According to Food and Drug Administration (FDA), the caloric requirement for adults and children as of the age of 4 years old is $2000 \mathrm{kcal}$ (= $8368 \mathrm{~kJ} /$ day). Thus, the energetic values of most of the species studied, including the exotics, represent more than $10 \%$ of the established reference daily intake (RDI).

Lauric acid was identified as the main fatty acid in the kernel of $A$. intumescens and in the two species of Syagrus (Table II). In accordance to Bora et al. (2003), kernels rich in lauric acid are a characteristic of palm oils. Species rich in lauric acid have numerous industrial applications. For example, they may be used in the food industry as cooking fats and as dairy fat replacements in margarines, biscuits, candies, and ice cream; they can also be used as a cocoa butter substitute. Oils rich in lauric acid are also very useful in soap and detergent manufacturing due their effects on surface tension (Arkcoll 1988, Bora et al. 2003).

Many vegetable oils, including palm oils, can be used for bioenergy production. The crude oil obtained from the kernel of $S$. coronata, for example, has characteristics that are favorable for biodiesel production (Teixeira da Silva de La Salles et al.2010). The seed production of $S$. coronata is estimated to be approximately $2000 \mathrm{~kg} / \mathrm{ha}$ (Drumond 2007). According to Gunstone (1996), traditional oilseeds have lipid content from 18\% such as soybean (18$20 \%$ oil), cotton (21\%) and canola (24-27\%). Since our studies showed that the kernels of the Syagrus species were rich sources of lipids (ranging from 30 to $40 \%$ ), their fatty acid composition, suggested that they may also be used as biofuel.

There are also several characteristics of $A$. intumescens that make it suitable for industrialization. This species presented a high oleic acid content in the pulp and a high lauric acid content in the kernel oil (Table II), which make it suitable for various industrial applications, some of which were previously mentioned here. Species with high oleic acid content (e.g., Jatropha curcas L.) have a significant potential for bioenergy. A. intumescens can produce 1800 liter/ha of oil (STI/MIC 1988). Although we have no current data at this time, this value is similar to that reported for $J$. curcas, which can produce 2000 liter/ha oil per year (Azam et al. 2005). In addition, the oil production of $A$. aculeata, another similar species, may reach $16000-25000 \mathrm{~kg}$ of fruit per hectare and may produce up to $6200 \mathrm{~kg} /$ ha of oil (Pires et al. 2013). In addition to the high oleic acid content, A. intumescens grows well in areas with low soil fertility, has tolerance to fire and can be cultivated in areas that undergo prolonged drought. These characteristics are ideal for biomass production in semi-arid areas.

Lipids stimulate the absorption of carotenoids; thus, carotenoids from palm fruits may have the 
additional advantage of greater bioavailability (Rodriguez-Amaya and Kimura 2004). In our studies, two species stand out as sources of carotenoids (Table III). P. kuhlii, the species with the greatest carotenoid content, showed an RAE level $(1515 \mu \mathrm{g} / 100 \mathrm{~g})$ similar to that measured for the peach palm (Bactris gasipaes Kunth) and almost twice that measured in the tucuma (Astrocaryum aculeatum G. Mey.), another Amazon palm (de Rosso and Mercadante 2007). This value is nearly three times lower than that of the buriti (Mauritia vinifera Mart.), a palm species that is considered an excellent source of provitamin A (RodriguezAmaya and Kimura 2004). The mean recommended vitamin A intake for adult women and men is 700 and $900 \mu \mathrm{g} /$ day, respectively (Trumbo et al. 2001). Approximately $50 \mathrm{~g}$ of $P$. kuhlii fruit would meet the daily vitamin A needs for a woman and more than half of the daily vitamin A needs for a man.

The fruits of A. intumescens are also rich sources of carotenoids (Table III). The carotenoid content of its pulp was higher than that of A. mokayayba Barb. Rodr. (Rodriguez-Amaya and Kimura 2004) but lower than that of $A$. aculeate (Coimbra and Jorge 2011). Despite higher levels of carotenoids than $P$. kuhlii, the consumption of $A$. intumescens appears to be more practical because, according to its popular use, the ripe fruits of $A$. intumescens have a fibrous mesocarp and are edible as well as tasty. Three or four fruits are sufficient to fulfill the RDI of vitamin A for adult men and women, because the pulp weighs approximately $20 \mathrm{~g}$.

The fruits of $P$. kuhlii are also very small compared to those of Syagrus. Thus, one or two Syagrus fruits are equivalent to $100 \mathrm{~g}$ of the fruits from the exotic plants studied. The pulp oil of $S$. coronata contained significantly more carotenoids than that of $S$. cearensis. Because the pulp of $S$. coronata weighs approximately $20 \mathrm{~g}$, two or three fruits are sufficient to satisfy the RDI of vitamin A for adult women or men. The $\beta$-carotene is the main vitamin in the pulp of $S$. coronata (Crepaldi et al. 2000). Thus, this species is an excellent source of provitamin A for rural populations in the Brazilian northeast, particularly because it is a typical palm that grows in semi-arid regions such as the Caatinga.

\section{CONCLUSIONS}

The results showed that the palm trees $A$. intumescens and $S$. coronata can be considered an alternative food sources as well as excellent sources of carotenoids underutilized. Due to the high lauric acid content in their kernel oils, these species can also be used in the food industry as cooking fats and dairy fat replacements. These species could also be used in the manufacture of soaps. The high oleic acid content of the pulp of $A$. intumescens also makes this species promising for the biofuel industry. Furthermore, in addition to its ornamental use, $P$. macarthurii was shown to be an excellent source of carbohydrates, ash and carotenoids. However, before P. macarthurii fruits can be used as a food source, further studies are required to confirm the absence of toxicity.

\section{ACKNOWLEDGMENTS}

The authors are thankful to the Coordenação de Aperfeiçoamento de Pessoal de Nível Superior (CAPES, Brazil) for providing a scholarship to the first author; and to the Food Experimentation and Analysis Laboratory (Nutrition Department, UFPE, Brazil) for their technical support.

\section{RESUMO}

Neste estudo, a polpa e a amêndoa de frutos de seis espécies de Arecaceae foram submetidos à análise centesimal, determinação da composição de ácidos graxos e análise do teor de carotenoides totais. As espécies com os maiores valores de carboidratos, lipídios e proteínas foram Ptychosperma macarthurii $(70,1 \mathrm{~g} / 100 \mathrm{~g}$ na amêndoa), Syagrus cearensis (40,6 g/100 g na amêndoa) e $S$. coronata $(20,6 \mathrm{~g} / 100 \mathrm{~g}$ na polpa). O teor de cinzas variou de 0,61 a 7,51 g/100 g. Láurico, palmítico e oleico 
foram os principais ácidos graxos identificados. O teor de carotenoides totais e equivalentes de atividade de retinol foram maiores nas polpas de Pinanaga kuhlii $(180,3 \mu \mathrm{g} / \mathrm{g})$ e Acrocomia intumescens $(138,0 \mu \mathrm{g} / \mathrm{g})$. Equivalente de atividade de retinol variou entre as espécies estudadas (456-1515 $\mu \mathrm{g}$ RAE/100 g). Espécies nativas como $A$. intumescens, $S$. coronata e $S$. cearensis são boas fontes de alimentos frescos para as populações carentes que habitam áreas pouco desenvolvidas, como a região semiárida do Brasil. P. macarthurii, uma espécie exótica, é uma excelente fonte de cinzas e carotenoides, demonstrando seu potencial como fonte de alimento e de compostos bioativos. A polpa e a amêndoa de $A$. intumescens, podem ser uma boa alternativa como matérias-primas para a produção de biodiesel e sabão, respectivamente.

Palavras-chave: biomassa, alimentos, ácido oleico, palmeiras.

\section{REFERENCES}

Ahmad MU, Husain SK And Osman SM. 1981. Ricinoleic acid in Phyllanthus niruri seed oil. J Am Oil Chem Soc 58: 673-674.

AOAC. 2000. Official methods of analysis of the Association of Official Analytical Chemists. $17^{\text {th }}$. Maryland: Gaithersburg.

ARKCOLL D. 1988. Lauric oil resources. Econ Bot 42: 195-205.

AZAM MM, WARIS A AND NAHAR NM. 2005. Prospects and potential of fatty acid methyl esters of some nontraditional seed oils for use as biodiesel in India. Biomass Bioenerg 29: 293-302.

BORA PS, ROCHA RV, NARAIN N AND MOREIRA-MONTEIRO AC. 2003. Characterization of principal nutritional components of Brazilian oil palm (Elaeis guineensis) fruits. Bioresource Technol 87: 1-5.

CoImbra MC AND Jorge N. 2001. Proximate composition of guariroba (Syagrus oleracea), jerivá (Syagrus romanzoffiana) and macaúba (Acrocomia aculeata) palm fruits. Food Res Int 44: 2139-2142.

Crepaldi IC, Almeida-Muradian LB, Rios MDG AND PENTEAdo MVC. 2000. Salatino A. Composição nutricional do fruto do licuri (Syagrus coronata (Martius) Beccari). Rev Bras Bot 24: 155-159.

De Rosso VV And MERCADANTE AZ. 2007. Identification and quantification of carotenoids, by HPLC-PDA-MS/MS, from Amazonian fruits. J Agr Food Chem 55: 5062-5072.

DRUMOND MA. 2007. Licuri Syagrus coronata (Mart.) Becc. Documentos 199. Petrolina: Embrapa Semiárido.

GUNSTONE FD. 1996. Fatty acid and lipid chemistry. New York: Blackie Academic \& Professional, p. 264.
Hiane PA, Bogo D, Ramos MIL and Ramos-Filho MM 2003. Carotenóides pró-vitamínicos a e composição em ácidos graxos do fruto e da farinha do bacuri (Scheelea phalerata Mart.). Cienc Tecnol Aliment 23: 206-209.

IOM -INSTITUTE OF MEDICINE. 2001. Dietary Reference Intakes for vitamin A, vitamin $\mathrm{K}$, arsenic, boron, chromium, copper, iodine, iron, manganese, molybdenum, nickel, silicon, vanadium, and zinc. Washington, DC: National Academy Press, p. 82-161.

JONES DB. 1941. Factors for converting percentages of nitrogen in foods and feeds into percentages of protein. Washington, DC: US Department of Agriculture, p. 22.

JONES DL. 2010. Palms in Australia: Biogeography, Ecology and Systematics. CSIRO Publishing.

LeITMAN P, Henderson A, Noblick L, MARTins RC AND SoARES K. 2014. ARECACEAE in Lista de Espécies da Flora do Brasil. Jardim Botânico do Rio de Janeiro. Available in: <http://floradobrasil.jbrj.gov.br/jabot/ floradobrasil/FB15662>. Access at 05 Sep. 2014.

Lorenzi H, Souza HM, Medeiros-Costa JT, CERQueIra LSC AND FERREIRA E. 2004. Palmeiras brasileiras e exóticas cultivadas. São Paulo: Nova Odessa. Instituto Plantarum de Estudos da Flora, p. 432.

MAYWORM MAS AND SALATINO A. 1996. Fatty acid composition of ‘cerrado' seed oils. J Sci Food Agr 72: 226-230.

Medeiros-CostaJT. 2002. As espécies de palmeiras (Arecaceae) do Estado de Pernambuco, Brasil). In: Tabarelli M and Silva JMC (Eds), Diagnóstico da Biodiversidade de Pernambuco. Recife: Sectma e Massangana 1: 229-236.

MENEZES EMS, TORRES AT AND SRUR AUS. 2008. Valor nutricional da polpa de açaí (Euterpe oleracea Mart) liofilizada. Acta Amazon 38: 311-316.

NASCIMENTO VT, MOURA NP, VASCONCELOS MAS, MACIEL MIS AND AlbuQuerque UP. 2011. Chemical characterization of native wild plants of dry seasonal forests of the semi-arid region of northeastern Brazil. Food Res Int 44: 2112-2119.

NASCIMENTO VT, VASCONCELOS MAS, MACIEL MIS AND ALBUQUERQUE UP. 2012. Famine foods of Brazil's seasonal dry forests: ethnobotanical and nutritional aspects. Econ Bot 66: 22-34.

Oliveira VB, YAMAdA LT, FAGG CW AND BRANDÃo MGL. 2012. Native foods from Brazilian biodiversity as a source of bioactive compounds. Food Res Int 48: 170-179.

PINHO RS, OliveIRA AFM AND SILVA SI. 2009. Potential oilseed crops from the semi-arid region of northeastern Brazil. Bioresource Technol 100: 6114-6117.

PIREs TP, Dos SAntos Souza E, KuKi KN AND Motoike SY. 2013. Ecophysiological traits of the macaw palm: A contribution towards the domestication of a novel oil crop. Ind Crop Prod 44: 200-210.

RoDrigueZ-AmAYA DB AND KIMURA K. 2004. HaverstPlus handbook for carotenoids analysis. HarvestPlus Technical Monograph 2. Washington, DC and Cali: International Food Policy Research Institute (IFPRI) and International Center for Tropical Agriculture (CIAT), p. 84. 
RODRIGUEZ-AMAYA DB, KiMURA M, GODOY HT AND AMAYAFARFAN J. 2008. Updated Brazilian on food carotenoids: factors affecting carotenoid composition. J Food Compos Anal 21: 445-463.

Rufino MUL, Costa JTM, Silva VA AND ANDRAde LHC. 2008. Knowledge and use of ouricuri (Syagrus coronata) and babaçu (Orbignya phalerata) in Buíque, Pernambuco State, Brazil. Acta Bot Bras 22: 1141-1149.

STI/MIC. 1988. Potencialidades do fruto da Acrocomia intumescens para fins energéticos. Brasília: Simpósio nacional sobre fontes novas e renováveis de energia.

TeiXeira da Silva de La SAlles K, Meneghetti SMP, Ferreira de La SAlles W, Meneghetti MR, Dos Santos ICF, Da Silva JPV, De CARVAlho SHV AND SolETTI JI. 2010. Characterization of Syagrus coronata (Mart.) Becc. oil and properties of methyl esters for use as biodiesel. Becc. oil and properties of methyl esters for use as biodiesel. Ind Crop Prod 32: 518-521.
TRUGO LC, DONANGELOCM, TRUGONMFANDBACHKNUDSEN K. 2000. Effect of heat treatment on nutritional quality of germinated legume seeds. J Agr Food Chem 48: 2082-2086.

Trumbo P, Yates AA, Schlicker S AND Poos M. 2001. Dietary Reference Intakes: Vitamin A, vitamin K, arsenic, boron, chromium, copper, iodine, iron, manganese, molybdenum, nickel, vanadium and zinc. J Am Diet Assoc 101: 294-300. 
